\title{
Od pariaski do Mesjaszki. Utopijna biografia Flory Tristan
}

Katarzyna Szumlewicz

TEKSTY DRUGIE 2019, NR 1, S. 339-352

DOI: 10.18318/td.2019.1.23 | ORCID: 0000-0002-8349-5031

$\mathbf{F}$ lora Tristan (1803-1844) to postać wielkiego formatu. Odważna i oryginalna, zmagała się jednocześnie $\mathrm{z}$ chorobą ciała i z brutalnymi regułami patriarchalnego porządku. Ważna dla nas, współczesnych, ponieważ zapoczątkowała dochodzący dziś do głosu sposób myślenia o społeczeństwie z perspektywy kobiecej pracy. Swoje przekonania wywodziła z socjalizmu utopijnego, który jednak przekształciła na podstawie własnych doświadczeń i płynącej z nich wrażliwości. Jednocześnie była osobą, która kształtowała i opisywała swoją biografię w sposób par excellence emancypacyjny. W niniejszym eseju przywołam zarówno okoliczności jej trudnego, krótkiego życia, jak i poglądy, które rozwijała i głosiła. Pokażę jej ogromną determinację i konsekwencję w dążeniu do sprawiedliwego porządku społecznego, a także zasługującą na podziw zbieżność jej poczynań i przekonań. Korzystam m.in. z biografii Flora Tristan. Life stories, spisanej przez Susan Grogan. Autorka używa w tytule liczby mnogiej, ponieważ jej zamierzeniem jest przedstawić kilka różnych ujęć biografii bohaterki czy wręcz
Katarzyna Szum-

lewicz - dr, adiunkt na Wydziale Stosowanych Nauk Społecznych i Resocjalizacji UW. Autorka książek Emancypacja przez wychowanie, czyli edukacja do wolności, równości i szczęścia (2011) oraz Miłość i ekonomia w literackich biografiach kobiet (2017). Publicystka, krytyczka literacka, wykładowczyni Gender Studies. W swoich interdyscyplinarnych badaniach zajmuje się przede wszystkim problemami nierówności i wykluczenia. 
kilka jej życiorysów. Owo podejście jest mi bliskie i będzie obecne choćby w podziale treści niniejszego eseju. To nie wszystko. Tristan, która sama była pisarką, a jednocześnie kobietą charyzmatyczną i piękną, wiodła życie przypominające powieść o wartkiej akcji. Współcześnie taka powieść została napisana, nosi tytuł Raj tuż za rogiem, a jej autorem jest Mario Vargas Llosa. Poniżej przytoczę fragmenty tej książki i odwołam się do jej zamysłu.

\section{Wyzwolenie pariaski}

Peruwiański pisarz zainteresował się postacią Tristan początkowo ze względu na jej pochodzenie. Otóż była ona pół-Peruwianką, jej ojciec należał do jednej z najbogatszych rodzin Limy. Niestety Florze Tristan najwyraźniej nie było sądzone zaznać dostatku materialnego. Jej ojciec bowiem zmarł, kiedy była dzieckiem, po czym okazało się, że nie mogła po nim dziedziczyć, gdyż małżeństwo jej rodziców w świetle ówczesnego francuskiego prawa było nieważne, a nieślubnym dzieciom nie przysługiwał spadek. Wychowywana w ubóstwie przez matkę Tristan nie uczęszczała do dobrych szkół i wcześnie musiała pójść do pracy. Została pomocnicą grawera. Jej pryncypał, André Chazal, nie mógł przejść obojętnie obok rozkwitającej, południowej urody siedemnastolatki. Szybko się w niej zakochał i zaczął o nią zabiegać. Dziewczynie jego zaloty były obojętne, natomiast jej matka wyczuła w nich możliwość poprawy losu córki, mającej ze względu na status bękarta słabą pozycję na rynku małżeńskim. Naciskała na nią, by przyjąć oświadczyny Chazala, co Flora faktycznie uczyniła. Zostali małżeństwem przed osiągnięciem przez nią pełnoletności, natomiast mąż miał 24 lata. Flora urodziła dwoje dzieci, po czym będąc w ciąży z trzecim, uciekła od Chazala. Okazało się, że nie czerpała żadnej satysfakcji z wymuszanego pożycia i bała się brutalności męża.

Niestety prawo brało całkowicie stronę mężczyzny w takich sporach. Stanowiło, że żona ma przystosowywać się do decyzji męża, mieszkać tam, gdzie on postanowi, i akceptować jego całkowitą kontrolę nad finansami. Tylko ojciec miał prawa do dzieci, nawet wdowy po śmierci mężów musiały walczyć o swoje potomstwo przed sądem. Zupełnie inaczej traktowano zdradę małżeńską u kobiet i mężczyzn. Żona mogła zażądać separacji i ukarania męża tylko wówczas, gdy ten przyprowadził kochankę na stałe do domu, natomiast udowodnioną zdradę małżeńską u kobiet karano więzieniem lub grzywną. Nawet morderstwo niewiernej żony mogło być uniewinnione jako zbrodnia płynąca z "uzasadnionego gniewu”. Mąż mógł „dyscyplinować” żonę także w innych kwestiach, o ile nie spowodował tym wyraźnego uszczerblku na jej 
zdrowiu. Jako że ciało żony prawnie należało do męża, nie istniało pojęcie wymuszonego seksu. Wszystkie te zasady wynikały z kodeksu Napoleona, traktującego kobietę jako „wieczyście małoletnią”. Z niego także brało się złe położenie Flory Tristan jako nieślubnego dziecka. Otóż mężczyzna był odpowiedzialny tylko za swoje dzieci narodzone w małżeństwie. Te urodzone poza nim pozbawione były nie tylko prawa do dziedziczenia, ale także wielu praw publicznych.

Tristan, uciekając z dziećmi, pozbawiona pieniędzy, musiała się ukrywać, a jednocześnie na bieżąco zarabiać, by utrzymać siebie i dzieci. Pracowała jako guwernantka i sprzedawczyni, otrzymując groszowe wynagrodzenie. W końcu podjęła decyzję, by pojechać do Peru na zaproszenie krewnych. Nie udało jej się wywalczyć spadku po ojcu, na co liczyła, ale uzyskała od zamożnej rodziny niewielką pensję, która odtąd przez parę lat stanowiła podstawę jej bytu. W tym czasie zaczęła pisać. Jako pierwszą wydała broszurę na temat tego, jak traktowane są kobiety-podróżniczki. Opisała tam m.in. bezustanne zdziwienie i oburzenie, że podróżuje bez męskiej asysty. Postulowała, by stworzyć zbiór zasad uprzejmego podejścia do samodzielnie podróżujących kobiet. Potem powstały Wędrówki pariaski, gdzie zrelacjonowała swoją ucieczkę od męża i wyprawę do Peru. Tytuł odnosi się do jej pozycji zamężnej kobiety, która nie może uzyskać rozwodu. $Z$ tej perspektywy Tristan barwnie opisuje inną kulturę, inne "naturalne” zachowania kobiet. Zastanawia się m.in. nad tym, jak na Peruwianki wpływa woal, zwany saya, za którym ukrywają twarz. Jak pisze, mieszkanki Limy

myślą inaczej niż ich siostry z Europy, od dziecka poddane prawom, wartościom, przesądom, stylom i wszystkiemu innemu. Otóż pod saya kobieta z Limy jest wolna, cieszy się niezależnością i z ufnością poddaje się sile, której podlega każda istota, o ile postępuje w zgodzie ze swoją naturą. Kobiety z Limy, niezależnie od swojej pozycji społecznej, są zawsze soba i jako takie nie podlegają ograniczeniom. Młode dziewczyny unikają dominacji rodziców dzięki swobodzie umożliwianej przez ich strój. Mężatki nie przybierają nazwiska męża, ale zatrzymują własne, jak przystało na władczynie swojego życia. Kiedy mają dosyć mężowskich czułości, zakładają swoje saya i idą gdzie chcą, tak samo niezależne jak mężczyźni. ${ }^{1}$

1 F. Tristan Peregrination of a Pariah, w: D. i P. Beik, Flora Tristan. Utopian Feminist, Bloomington \& Indianapolis 1993, s. 32. 
Ten oraz inne opisy i refleksje zawarte w Wędrówkach pariaski, choć nie były napisane nieskazitelną francuszczyzną i choć sama autorka wzbudzała spore kontrowersje, bardzo spodobały się publiczności we Francji. Oznaczało to kolejny zarobek - który Tristan przeznaczyła na dalsze podróże - a także rodzącą się sławę, która jednak nie pomogła jej w rozgrywkach z mężem. Skoro bowiem była rozpoznawalna, łatwiej było ją znaleźć i odebrać jej dzieci. Chazal początkowo nie upominał się o nie, ponieważ stał się bankrutem, niemogącym ich utrzymać. Potem jednak, sądząc, że żona otrzymała spadek od krewnych i zarabia krocie na pisaniu, zaczą dążyć do tego, by odebrać jej w majestacie prawa najpierw dzieci, a potem pieniądze. Tristan, pragnąc ugody, oddała mu starszego chłopca, Ernesta, pozostawiając przy sobie młodszą dziewczynkę, Alinę (średni chłopiec zmarł). Chazal tymczasem najbardziej chciał odzyskać córkę. W pewnym momencie udało mu się ją porwać. Następnie doszło do sądowego porozumienia, na mocy którego dziewczynka trafiła do internatu, gdzie mogli ją odwiedzać i ojciec, i matka. Potem znowu przez jakiś czas przebywała u ojca, gdzie panowało takie ubóstwo, że razem z nim i bratem musiała spać w jednym łóżku. Alina skarżyła się, że jest przez Chazala dotykana w niechciany przez nią sposób, co potwierdził jej brat. Flora zgłosiła te skargi do sądu, który jednak je oddalił. Chazal nie czuł się usatysfakcjonowany, mimo że organa prawa wyraźnie go faworyzowały. Uważał się za porządnego obywatela, śmiertelnie obrażonego i pokrzywdzonego przez odejście kobiety, która powinna była go przecież we wszystkim słuchać. Opublikował nawet pamflet przeciwko Tristan, za co nie poniósł żadnych prawnych konsekwencji poza tym, że Florze na jego podstawie wreszcie udało się uzyskać separację. Mężczyznę to rozwścieczyło, wpadł w manię prześladowczą. Postanowił „ukarać” matkę swoich dzieci... śmiercią.

Kupił w tym celu dwa pistolety, zaczaił się na żonę i do niej strzelił, celując w serce. Jedna z kul utkwiła w płucu, lekarzom mimo wysiłków nie udało się jej usunąć. Od tej pory Flora Tristan nie była w pełni sprawna, a jej życie zaczął wypełniać nawracający, ostry ból. Nie powstrzymał jej on od gorączkowego działania i licznych podróży. Nie ulega wątpliwości, że to właśnie w wyniku mężowskiego postrzału żyła tylko 41 lat. Dopiero usiłowanie morderstwa sprawiło, że Tristan uzyskała rozwód, a Chazal został skazany na 20 lat galer. Warto mieć na uwadze, że za żaden z wcześniejszych aktów przemocy nie poniósł kary. Uszła mu płazem przemoc domowa i zmuszanie żony do seksu, a także późniejsze szkalowanie jej na forum publicznym. Nie został ukarany za kilkakrotne porwanie córki, która się go bała i której nie umiał, podobnie jak synowi, zapewnić godziwych warunków życia. Wreszcie oczyszczono go 
z potwierdzonego przez Ernesta zarzutu molestowania seksualnego Aliny, przed którym bronił się, twierdząc, że dziewczynka oskarża go o lubieżne zachowania, ponieważ została skażona niemoralnością gardzącej życiem rodzinnym matki...

Odwołanie do kultu patriarchalnej rodziny gwarantowało Chazalowi zrozumienie u jemu współczesnych. Jego żona, opuszczając ognisko domowe i poruszając się samodzielnie po świecie, w powszechnym odczuciu naruszyła uświęcone role rodzicielskie i płciowe. Co gorsza, swój wzorzec postępowania przekazywała córce, która mogła przez to utracić „kobiece” cechy potulności i posłuszeństwa! Było to celne zagranie pod publikę, jak się jednak okazało, Tristan również świetnie potrafiła rozegrać swoją sytuację. Zamiast uciekać w milczeniu i upokarzającej świadomości, że opinia publiczna uważa ją za wyrzutka, nazwała sama siebie „pariaską”, czym wzięła na siebie z góry to potępienie i je podważyła. W ten sposób zwróciła uwagę na problem, z którym nieustannie się zmagała: brak praw kobiet w małżeństwie i niemożność jego opuszczenia. Nawet ci, którzy się z nią nie zgadzali, musieli przyjąć do wiadomości jej argumenty. Co więcej, oburzone głosy przyczyniły się do zainteresowania książką i jej autorką. Innymi słowy, Tristan ze swojej dramatycznej ucieczki stworzyła gest emancypacji, upełnomocnienia. Jak również reklamy. Susan Grogan w zakończeniu rozdziału dotyczącego Wędrówek pariaski twierdzi, że rozgłos wokół tej książki i rozstania z mężem uczynił z niej kogoś, kogo dzisiaj określamy mianem celebryty ${ }^{2}$. Do celów reklamy Tristan wykorzystała nawet utratę zdrowia.

\section{Po stronie uciśnionych}

Pisarka doskonale czuła się w roli osoby skupiającej publiczne zainteresowanie. Umiała je przekierować na palące problemy jej czasów (które pozostają aktualne do dziś). Pierwszym była podrzędna społeczna pozycja kobiet, ich niższy status w małżeństwie i rodzinie. Drugim - straszna sytuacja ludzi pracy, u kobiet jeszcze dotkliwsza niż u mężczyzn ze względu na dekretowaną prawem i popartą obyczajem nierówność płciową.

Następną publikacją Tristan była powieść Mephis, w której bezkompromisowa, silna bohaterka imieniem Marequita, marzy o wypuszczaniu więźniów i radykalnej przebudowie społeczeństwa. Jej towarzyszem jest tytułowy Mephis, przedstawiciel budzącego lęk Mefistofelesa - proletariatu. Później

2 S. Grogan Flora Tristan. Life Stories, London-New York 1998, s. 43. 
następują Promenady w Londynie napisane po podróży do stolicy Wielkiej Brytanii. Londyn w tamtym czasie był najbogatszym miastem świata. Słynął m.in. z oświetlenia gazowego, które wprowadzono w nim jako pierwszym mieście na świecie. Tristan relacjonuje rozmowy z pracownikami gazowni, silnymi mężczyznami, którzy z gorąca panującego w pracy wychodzą prosto na mróz. Dowiaduje się od nich, że ceną za magiczne oświetlenie jest gruźlica, na którą zapadają średnio po siedmiu latach owej pracy.

Potworny wyzysk robotników, niemających alternatywy w postaci lżejszej pracy, widzi Tristan dosłownie na każdym kroku. Londyńczycy z klas niższych są w większości chorzy, wynędzniali, bez praw do leczenia. Wiele osób, usiłując przetrwać, łamie restrykcyjne prawo, po czym zostaje osadzonych w zakładach karnych. Tristan opisuje upiorne angielskie więzienia. Wskazuje, że większość uwięzionych kobiet to młode prostytutki, często zamknięte wraz ze swoimi dziećmi. Londyn XIX stulecia był miastem o rekordowej liczbie prostytutek przypadających na jednego mężczyznę. Tristan traktuje to zjawisko jako pokłosie skrajnego rozwarstwienia ekonomicznego przy jednoczesnym ograniczeniu prawa kobiet do zarabiania pieniędzy i ich posiadania.Z jej rozmów z prostytutkami wyłania się obraz finansowej desperacji, bezwzględnie wykorzystywanej przez mężczyzn z klas wyższych. Tropiąc społeczne wykluczenie, pisarka odwiedza także slumsy zamieszkane przez Irlandczyków. Opisuje niezwykle trudne warunki życia, straszliwą krzywdę dzieci, upokorzenie matek. Polemizuje z popularnym wówczas maltuzjanizmem, czyli przekonaniem, że najubożsi powinni wymrzeć lub powstrzymać się od rozmnażania. Zwraca uwagę, że w sytuacji ucisku ekonomicznego kobiety ze wszystkich grup etnicznych są traktowane najgorzej, najmniej jedzą, najrzadziej się je leczy, najczęściej doświadczają przemocy i gwałtu. Wyciąga stąd wniosek, że nie wystarczy podwyższenie zarobków i polepszenie warunków pracy mężczyzn, co postulowała wówczas duża część ruchu pracowniczego (chociażby czartyści domagali się, by mężczyzna zarabiał tyle, aby móc utrzymać niepracująca żonę, co zakładało wypchnięcie kobiet z rynku pracy i zachowanie hierarchii domowej). Kobietom z klasy pracującej należą się według niej godne pensje, ochrona zdrowia, dostęp do edukacji, publiczne wsparcie w niedocenianej, fundamentalnej pracy wychowywania dzieci, a przede wszystkim szacunek społeczeństwa, co oznacza pełnię praw obywatelskich.

Tristan, wyruszając do Londynu, miała na uwadze dzieła wybitnych pisarek angielskich, przede wszystkim Mary Wollstonecraft, która w swojej słynnej książce domagała się dla kobiet tych samych praw, wskazując na absurd 
powierzania wychowania dzieci osobom, którym odbiera się możliwość decydowania o tym, w jakim świecie będą żyły przyszłe pokolenia ${ }^{3}$. W Promenadach $w$ Londynie Tristan wyraża swoje ogromne zdziwienie, że w kraju, gdzie sformułowano najlepsze argumenty na rzecz praw kobiet i gdzie ujawnił się kobiecy geniusz, obowiązują, podobnie jak we Francji, prawa tak bardzo krzywdzące kobiety. Angielki, wychodząc za mąż, traciły prawo do swoich pieniędzy, a rozwieść się nie mogły. Nie dysponowały czynnym ani biernym prawem wyborczym. Co więcej, nie mogły nawet wejść do budynku Parlamentu, uważanego za wzorcowy przybytek demokracji! Tristan postanowiła zatem przebrać się za mężczyznę, by wejść do zakazanego miejsca. Opisuje, jak kolejni posłowie odmawiali jej współpracy, na którą zgodził się dopiero reprezentant mniejszości tureckiej. Przebrana za wyznawcę islamu obejrzała wnętrza zabronione przedstawicielkom swojej płci, po czym została wyproszona, ponieważ wyszło na jaw jej oszustwo. Zobaczyła jednak, co trzeba: posłów niechlujnie ubranych, ziewających i przysypiających. Zupełnie bez szacunku dla doniosłości pełnionej funkcji! Przeciwko obecności posłanek w Parlamencie wysuwano wówczas „argument”, że nie umiałyby uszanować powagi miejsca, w którym na pewno by chichotały, plotkowały i szydełkowały. W relacji Tristan uderza jeszcze jedna kwestia. Swojego ubrania użyczył jej przedstawiciel świata muzułmańskiego, uważanego za „barbarzyński” i piętnowanego m.in. za stosunek do kobiet, natomiast „światli” Anglicy jej tego odmówili. Być może zatem przewaga „cywilizacji” była pod tym względem - jak i pod wieloma innymi - życzeniowa, fikcyjna?

Podczas podróży do Londynu Tristan zapoznała się z poglądami Roberta Owena. Socjalizm utopijny znała dobrze z Francji, korespondowała m.in. z Charles'em Fourierem, twórcą pomysłu Falansterów, czyli łączących miasto i wieś pokojowych społeczności, w których ludzie cieszą się wykonywaną pracą, zaś prace domowe i wychowanie dzieci, zwykle przypisywane kobietom, są całkowicie uspołecznione, co w połączeniu ze swobodą erotyczną, pozwala na zniesienie rodziny jako miejsca ucisku kobiet. Jednak utopia Anglika okazała się o wiele trwalszą inspiracją. Owen był skuteczny i wpływowy. Jako poseł do Parlamentu wywalczył skrócenie dnia roboczego i zakaz pracy dzieci do 12. roku życia. Wokół swojej tkalni w New Lanark z lokalnej społeczności, zagrożonej marginalizacją, stworzył dobrze funkcjonującą komunę, gdzie

3 M. Wollstonecraft Wołanie o prawa kobiety, przeł. E. Bodal, M. Cichoń, L. Dymek, K. Hilbright, M. Iwanek, M. Jermacz, H. Morusiewicz, A. Skalniak, B. Sowiński, A. Sprzęczka, N. Strehlau, A. Weseli, Wydawnictwo Mamania, Kraków 2002. 
zapewnił dorosłym godne warunki pracy i życie kulturalne, a dzieciom naukę, zabawę i opiekę w świetlicach. W opartej na doświadczeniach z New Lanark wizji idealnego społeczeństwa wszyscy byli wychowywani kolektywnie do równości i odpowiedzialności za ogół. Kobiety i mężczyźni mieli na równi rządzić, dysponować własnością i cieszyć się życiem. Owen postulował, by rozwody były dopuszczalne i by znikła kategoria dzieci nieślubnych. Uważał, że kobiety powinny mieć prawo do przedmałżeńskich doświadczeń seksualnych, tak jak mężczyźni. Sądził, że niedobranie pod tym względem stanowi źródło wielu samobójstw. Krytykował angielski system penitencjarny, stojący na straży własności i za nic mający realnych ludzi. Wskazywał, że tzw. przestępcy z klas niższych byli skazani na długo przed tym, jak popełnili karalne czyny. System ekonomiczny nie dawał im bowiem od dziecka żadnych szans życia na normalnym poziomie. Angielskie prawo zresztą karało także dzieci, co dla Owena było skandalem, podobnie jak sama ich praca. Owen zachęcał pracowników i pracownice do zrzeszania się w związkach zawodowych. Uważał, że ze względu na liczebność proletariatu są one w stanie pokojowo przekształcić kapitalizm w system sprawiedliwości i dobrobytu".

Pod wpływem Owena Tristan tworzy własny system. Po Promenadach w Londynie pisze Jedność robotnicza, zarys społeczeństwa idealnego i sposobu przejścia do niego. Tytułowa jedność to związek zawodowy, obejmujący wszystkich robotników i robotnice. Do tej grupy zalicza poza proletariatem przemysłowym i chłopstwem m.in. służące. Mają się oni przekształcić w klasę i wyartykułować swoje interesy przez wyłonienie politycznej reprezentacji. Tristan domaga się polepszenia warunków pracy i skrócenia czasu jej trwania oraz zapewnienia pracownikom godnej opieki medycznej. Niewielkie składki członków związku mają pomóc w uniknięciu najgorszych bolączek kapitalizmu. Należy do nich to, co dzieje się z ludźmi już niezdolnymi do pracy z powodu wyczerpania, starości czy wypadków, którzy nie otrzymywali odszkodowań ani tym bardziej emerytur, nie zawsze mieli nawet prawo do leczenia. Składka, przypominająca tworzone wówczas w kręgach rzemieślniczych dobrowolne kasy chorych, ma być wydana na przybytki opieki dla niezdolnych do pracy. Mają to być, jak u Fouriera, pałace robotnicze w pięknym otoczeniu. Tam też ma się odbywać edukacja wszystkich robotniczych

4 Poglądy Roberta Owena i Charlesa Fouriera referuję szczegółowo w swojej książce Emancypacja przez wychowanie, w której poświęcam im rozdział zatytułowany: Konstrukcje nadziei w utopiach edukacyjnych Owena i Fouriera (por. K. Szumlewicz Emancypacja przez wychowanie, czyli edukacja do wolności, równości i szczęścia, Sopot 2011, s. 205-256). 
dzieci.Towarzyszące szkołom świetlice, jak również dostępne dla wszystkich żłobki mają pomóc matkom z klasy robotniczej wieść niezależne życie. Własność zarobiona przez kobietę będzie należeć do niej, nie do jej partnera, co było wcześniej jednym z najważniejszych postulatów Mary Wollstonecraft.

\section{Kwestia erotyzmu}

Kobiety mają odzyskać seksualność, dotychczas podporządkowaną mężczyznom. Zniesione mają zostać kary za niewierność i ograniczenia praw nieślubnych dzieci, a także przyznawania dzieci mężczyznom jako ich prawnym opiekunom. Niedopasowanie seksualne ma stać się dostatecznym usprawiedliwieniem rozwodu. W niektórych miejscach Tristan wprost twierdzi, że małżeństwo powinno zostać zniesione na rzecz spontanicznych, dobrowolnych związków. Już w powieści Mephis akcentuje, że kobieca swoboda to coś więcej niż uwolnienie od przymusu i gwałtu. Tak opisuje swoje przesłanie jednemu ze swoich wielbicieli (być może kochanków), Charles'owi Filleu:

Domagając się niezależności kobiety, żądając, by była ona absolutnie pod każdym względem wolna, pragnę, by to ona przejmowała inicjatywę w miłości. Aby do mężczyzny, którego kocha, mówiła „kocham cię, czy chcesz być mój?"5

By docenić doniosłość tych żądań, należy porównać je z wizją Engelsa, według którego dzięki socjalizmowi nadejdzie

pokolenie mężczyzn, którym nigdy nie zdarzyło się kupić kobiety za pieniądze lub za pomocą innych społecznych środków potęgi, i pokolenie kobiet, którym nigdy nie zdarzyło się oddać mężczyźnie z jakichkolwiek innych względów niż z prawdziwej miłości ani też odmówić ukochanemu z obawy przed następstwami ekonomicznymi. ${ }^{6}$

Engels najwyraźniej zakładał, że mężczyźni zawsze będą tymi, którzy inicjują stosunki seksualne, zaś kobiety zawsze będą im się „oddawać”, tyle że

5 F. Tristan, list do Charles'a Filleu z 1843 r., cyt. za: S. Grogan Flora Tristan, s. 142.

6 F. Engels, O pochodzeniu rodziny, własności prywatnej i państwa, w: K. Marks, F. Engels Dzieła, t. 21, Warszawa 1969, s. 88. 
w socjalizmie nie będzie to zachodzić pod przymusem czy dla zarobku, pozwalającego wyjść z ubóstwa...

Tak jak później Engels, Tristan uważa, że w socjalizmie nie ma miejsca na prostytucję, czym różni się od spojrzenia chociażby Fouriera, w którego utopii seks ma zostać wyzwolony, a wszystkie możliwe pragnienia zarówno kobiet, jak i mężczyzn, spełnione, o ile nie prowadzą do czyjejś krzywdy. Realizacja pragnień następować ma przede wszystkim z ludźmi o pragnieniach komplementarnych, filozof jednak zakłada, że istnieć będą osoby, które uprawiają seks jako akt miłosierdzia lub dla zysku. Poglądy Tristan na seks warto odnieść do kontekstu jej życia. Była ona negatywnie nastawiona do wyzwalania męskiego libido, które kojarzyło jej się z nieuwzględnianiem życzeń kobiet, czy chodziło o kupowanie seksu, czy o egzekwowanie „małżeńskich powinności”. Tristan nie była jednak pruderyjna ani moralizatorska. Prowadziła z mężczyznami uwodzicielskie gry, angażowała się we flirty. Cieszyła się ogromnym powodzeniem i lubiła hołdy składane jej urodzie. Jednocześnie wiedziała, że najdrobniejszy romans stanowiłby doskonałą broń dla jej przeciwników. Jako kobieta, która rościła sobie prawa do bycia osobą publiczną, nie stawała się w powszechnym odczuciu obywatelką, lecz osobą permanentnie podejrzaną o „zepsucie”. Kobieca seksualność była uważana za zagrożenie dla ładu obywatelskiego, co wywodziło się jeszcze z wizji umowy społecznej Rousseau, na której opierał się w dużej mierze kodeks Napoleona. Dodatkowo Tristan była żoną, która odeszła od męża; mogło to rodzić przypuszczenie, że właśnie po to, aby mieć kochanków. Nie istnieją jednak żadne dowody, że tak było. Dbała o wizerunek kobiety, która nie prowadzi aktywności erotycznej. Grogan nie wyklucza, że Tristan jednak miewała relacje z mężczyznami, tyle że bardzo dobrze je ukrywała, także przed przyszłymi czytelnikami, co oznacza m.in., że nie zwierzała się z nich w korespondencji.

Dzięki jej listom wiemy natomiast na pewno, że miała co najmniej jeden długotrwały, skonsumowany związek z kobietą. Jej kochanką była polska emigrantka, arystokratka Olimpia Maleszewska. Korespondencja obu kobiet zawiera zmysłowe wyznania i przywołuje za pomocą kwiecistych metafor konkretną cielesną rozkosz. Według relacji Llosy, który pozostaje wierny faktom biograficznym, Olimpia i Flora poznały się na balu maskowym. W Raju tuż za rogiem arystokratka, zachwycona urodą bohaterki, zaprasza ją na spotkanie u siebie w salonie. Flora do niej przychodzi kilka razy. Za którymś razem podczas pożegnania Olimpia całuje Florę w usta, na co ta reaguje o wiele mocniej niż na czułości mężczyzn. Po niedługim czasie zostają kochankami. Llosa tak opisuje wpływ Olimpii na życie swojej bohaterki: 
Nauczyła cię przeżywać prawdziwą rozkosz, Florita, tak, i to wielką rozkosz, kiedy minęły pierwsze chwile zakłopotania i lęku. Sprawiła, że poczułaś się piękna, pożądana, młoda, kobieca. Olimpia nauczyła cię, że nie należy czuć lęku ani obrzydzenia do aktu seksualnego, że uleganie pożądaniu, głębokie przeżycie zmysłowych pieszczot, rozkoszowanie się cielesnymi przyjemnościami - to uroki intensywnego i pełnego pasji życia, nawet jeśli trwa krótko, może tylko kilka chwil. Cóż za wspaniały egoizm, Florita. Odkrycie fizycznej przyjemności przeżywanej bez przemocy z drugą istotą tej samej płci sprawiło, że poczułaś się kobietą pełniejszą i wyzwoloną. Jednak nawet wtedy, gdy byłaś najszczęśliwsza w towarzystwie Olimpii, oddając się cielesnym rozkoszom, nie potrafiłaś pozbyć się poczucia winy, przekonania, że trwonisz swoje siły i marnotrawisz wartości moralne. ${ }^{7}$

\section{Męczeństwo i wizje zbawienia}

Llosa uchwycił w tym opisie ważny rys charakteru Tristan. Otóż uważała ona, że ma misję, której powinna poświęcić wszystkie swoje uczucia. Nazywała siebie z tego powodu „kochanką ludzkości”. Tristan po napisaniu Jedności robotniczej zaczęła jeździć po całej Francji, zwołując wiece dla robotników, na których głosiła swoje przekonania. Jej postać wzbudzała ogromne zainteresowanie, nie tylko wśród proletariatu. Przeprowadzała mnóstwo rozmów z przedstawicielami kapitału i duchowieństwa, których nie zniechęcał jej skrajnie negatywny stosunek do obu tych instytucji. Jednocześnie odwiedzała zakłady pracy, więzienia i slumsy, gdzie badała warunki życia. Potrafiła porwać tłumy, liczba jej zwolenników, a zarazem członków i członkiń Jedności Robotniczej, rosła z dnia na dzień. Tymczasem kula w płucu doskwierała jej coraz bardziej. Cierpiała na coraz częstsze ataki przeszywającego bólu i zasłabnięcia, po których rzucała się w dalszą gorączkową aktywność. Pomagała jej w tym oddana sprawie robotnica Eleonore Blanc (która pod wpływem dotyku Flory przeżywała dreszcze ekstazy). Jednak ilość wysiłku, wkładanego w działalność polityczną, była u Tristan nadal nieproporcjonalnie wielka w porównaniu do jej sił.

Tristan zdawała sobie sprawę z pogarszania się stanu swojego zdrowia,jednak nawoływanie do przebudowy społeczeństwa było dla niej kwestią nadrzędną, rodzajem namiętności. Wtedy właśnie mianowała siebie Mesjaszką.

7 M. Vargas Llosa Raj tuż za rogiem, Poznań 2003, s. 356. 
Uważała, że swoją działalnością prowadzi ludzi do zbawienia. Rozumiała je jednak konkretnie, jako poprawę warunków życia proletariatu, a nie, jak chrześcijaństwo, jego odnowę moralną. Swoje cierpienie uznawała za cenę, którą warto zapłacić za radykalne ulepszenie społeczeństwa. Niewątpliwie uważała się za męczennicę słusznej sprawy. Męczeństwo dostrzegała jednak przede wszystkim w cierpieniach ludzi, zwłaszcza kobiet, padających ofiarą ustroju kapitalistycznego. W jej ostatniej książce Podróź po Francji znajdziemy opis praczek z Nîmes, bardzo religijnego miasta, w którym niewiele osób było zainteresowanych przystępowaniem do Jedności Robotniczej. Kilkaset kobiet prało len, stojąc po pas w wodzie w wielkiej, półnaturalnej fontannie. Robiły to przy palącym słońcu, w deszczu i przy wiejącym zimnym wietrze. Woda była brudna, pełna mydlin, sody, potasu, wybielaczy, smarów, barwników. Wynikiem tej pracy był reumatyzm i choroby narządów rodnych. Ciąże praczek były bardzo bolesne, często kończyły się poronieniami. Dzieci rodziły się słabe lub z deformacjami. Ciała kobiet były opuchnięte, kobiety te miały powykrzywiane stawy i choroby skórne. Tristan nie wyobraża sobie, by na takie męki można było skazywać najgorszych kryminalistów. Tymczasem

o los tych nieszczęsnych praczek, które nie popełniły żadnego przestępstwa, które pracują dzień i noc, poświęcając swoje życie i zdrowie w służbie ludzkości; o ich sprawę jako kobiet i matek, tak bardzo zasługujących na odruch szczodrego serca, nie troszczą się żadni dobroczyńcy ani dziennikarze! ${ }^{8}$.

Tristan umarła w trakcie podróży po Francji. Po jej śmierci przywództwo w Jedności Robotniczej przejęła Eleonore Blanc, która wprowadziła parareligijny kult założycielki. Alina, skrzywdzona przez ojca córka Flory, wyrosła na smutną kobietę. Popierała poglądy matki, ale nie angażowała się w działalność założonego przez nią związku. Postępowanie Chazala i oddzielenie w decydującym momencie od Flory sprawiły, że Alina nigdy nie wykazywała cienia jej energii i pewności siebie. Wyszła za mąż za namową przyjaciół, chcących poprawić jej los; jej status dziecka rozwiedzionych rodziców przypominał bowiem sytuację Tristan, gdy ta wychodziła za Chazala. Z małżeństwa Aliny urodził się syn, Paul Gaugin, który odziedziczył namiętny temperament babki. Llosa w książce, poświęconej im obojgu, za ich wspólną cechę uznał przede wszystkim to, co sygnalizuje w tytule: uporczywe, ambitne

8 F. Tristan The Tour of France, w: D. i B. Beik, Flora Tristan, s. 167. 
poszukiwanie raju, co stanowi istotę myślenia utopijnego. Malarz wcielał je w sztuce i w podróżach. Tak jak babka, chorował i spalał się w intensywnym działaniu. Miał jednak zasadniczo różny od niej stosunek do seksu. Czytając o jego współżyciu z nieletnimi Tahitankami, które narażał na zakażenie syfilisem, nabytym prawdopodobnie w jednym z europejskich burdeli, trudno nie przyznać racji Tristan, że wyzwolenie męskiej seksualności (malarz nim zaczął szukać seksualnych wrażeń z prostytutkami, dusił się w małżeństwie z purytańską żoną) nie może być traktowane jako kwestia priorytetowa przy tworzeniu sprawiedliwego, szczęśliwego społeczeństwa... Z drugiej strony warto docenić jego odziedziczoną po babce niechęć do europocentryzmu i otwartość na nienormatywną seksualność 9 .

Jeszcze jeden wątek wart jest przywołania w tym eseju. Tristan była wobec Aliny matką nieobecną, najpierw z powodu orzeczenia sądu, następnie zaś ze względu na swoją aktywność społeczną. Jednocześnie zdawała sobie sprawę z tego, jak bardzo potrzebna ludziom jest macierzyńska troska. Wśród nazw, jakimi się ochrzciła, znajdziemy między innymi „matkę robotników”. Zamiast zarzucać jej, że nie mogła jednocześnie ratować emocjonalnie wkraczającej w dorosłość córki i zbawiać ludzkości od bolączek kapitalizmu, lepiej przyjrzeć się jej poglądom w tej kwestii. Tristan uważała, że opiekuńcza bliskość, wymagana od matek i faktycznie przez nie na ogół wykazywana, powinna przekształcić się z prywatnego uczucia w podejście publiczne, zacząć przepajać całość życia społecznego. Nic nie stoi na przeszkodzie, by wszyscy dbali o siebie nawzajem; by cielesne i psychiczne zdrowie oraz bezpieczeństwo wszystkich, dzieci i dorosłych, jak również ich rozwój emocjonalny i umiejętność cieszenia się życiem, były zadaniami nie tylko dla ich matek. Uważam ten przekaz za niezwykle mądry i przenikliwy. Z tego punktu widzenia można spojrzeć zarówno na kwestie pracownicze, jak i na relacje uczuciowe. Jest to także świetny program funkcjonowania społeczeństwa, by opierało się ono na wolności i równości, a jednocześnie, by było wspierające, opiekuńcze, nastawione na szczęście i rozkwit w różnych dziedzinach życia.

9 Gaugin bardzo krytykował politykę kolonialną, a na Tahiti wyruszył w poszukiwaniu podejścia do życia, nietkniętego instrumentalnym podejściem Europejczyków. Odnosił się ze zrozumieniem do przedstawicieli „trzeciej płci” i sprzeciwiał się ich prześladowaniu przez chrześcijańskich misjonarzy. 


\section{Abstract}

\section{Katarzyna Szumlewicz}

UNIVERSITY OFWARSAW

From Pariah to Messiah: Flora Tristan's Utopian Biography

Szumlewicz explores the life and work of Flora Tristan (1803-1844), a Franco-Peruvian writer and social activist. Tristan's father belonged to the Peruvian aristocracy, but she lived in poverty because, according to French law, she was not entitled to her inheritance. She married early and had three children before leaving her violent husband. Again, the laws were against her, denying her child custody as well as the right to divorce. Tristan travelled to Peru hoping her relatives would help her. She described her journey, as well as the situation of a woman who cannot divorce, in Peregrinations of a Pariah. Next she travelled to England, where she developed her own version of Utopian Socialism emphasising the advancement of women. Tristan presented herself as "the mother of workers" and a "Messiah". She died at the age of 41 as a result of a gun-shot wound inflicted by her husband six years earlier.

\section{Keywords}

Utopian socialism, capitalism, exploitation, emancipation of women, motherhood, sexuality 